\title{
BIOSYNTHESIS OF POLYENE ANTIBIOTICS AND PHYTOHORMONES BY STREPTOMYCES NETROPSIS IMV AC-5025 UNDER THE ACTION OF EXOGENOUS ISOPENTENYLADENOSINE
}

\author{
M.I. Loboda, L.O. Biliavska, G.O. Iutynska \\ Zabolotny Institute of Microbiology and Virology, NAS of Ukraine, \\ 154 Acad. Zabolotny Str., Kyiv, 03143, Ukraine \\ e-mail:marichka20loboda@gmail.com
}

\begin{abstract}
Streptomyces are active producers of a wide range of metabolites with multidirectional biological activity. Streptomyces netropsis IMV Ac-5025 synthesizes a polyene antibiotic complex in which two fractions were identified: heptaene candidine and a new tetraene fraction of unknown structure. The influence of secondary metabolites on the polyene antibiotics biosynthesis by soil streptomycetes is insufficiently explored. The aim of this work was to research the effect of exogenous isopentenyladenosine on the biosynthesis of polyene antibiotics and cytokinins by S. netropsis IMV Ac-5025. Methods. The strain was cultured in submerged cultivation condition in organic (soy) and synthetic (starch-ammonia) liquid nutrient media. The studies of biomass accumulation (gravimetric method), glucose consumption (glucose oxidase method), pH changes of culture media (ionometric method), biosynthesis of polyene antibiotics, and phytohormones (quantitative and qualitative thin layer chromatography spectrodensitometric method) were conducted. The results were analyzed in Statisticav.6.0 program. Results. It was found that polyene antibiotics are synthesized after the first day of cultivation, which indicates their role in the metabolism of streptomycetes. The biggest amount of the polyene antibiotics was accumulated in the stationary phase of producer growth (on the $7^{\text {th }}$ day). It was found the decrease of polyene antibiotics and cytokinins accumulation in the producer's biomass with the increase of exogenous cytokinin concentration from $25 \mathrm{ng} / \mathrm{mL}$ to $500 \mathrm{ng} / \mathrm{mL}$. The bioproduction of the tetraene fraction was suppressed to a greater extentup to $92 \%$ in the synthetic and up to $23 \%$ - in organic nutrient media. However, the amount of producer biomass increased under the action of the exogenous substance that confirming the positive effect of exogenous cytokinin on cell division of S. netropsis IMV Ac-5025. Exogenous isopentenyladenosine reduced the accumulation of endogenous cytokinins in streptomycetes biomass. Conclusions. The obtained results indicate an indirect metabolic relationship between the biosynthesis of polyene antibiotics and cytokinins in soil streptomycetes and provide a basis for the regulation of the biotechnological process for bioproduct formation with the appropriate quantitative composition of its components.
\end{abstract}

Keywords: Streptomyces netropsis, polyene antibiotics, candidine, tetraene, biosynthesis of metabolites, cytokinins, isopentenyladenosine.

Representatives of the Streptomyces genus belonging to Actinobacteria family are aerobic gram-positive soil bacteria with mycelial morphology. They produce a wide range of antibiotics, which have different chemical structure and spectrum of activity. According to the chemical structure, these can be macrocyclic lactones, quinones, aromatic compounds, aminoglycosides, peptides, etc. [1].

The mechanism of their action is different: inhibition of bacterial cell walls biosynthesis, dysfunction of cell membranes, inhibition of the biosynthesis of purines, pyrimidines, nucleic acids, influence on the functioning of energy metabolism, in particular oxidative phosphorylation, etc. The production of most of antibiotics is a strain characteristic and depends on the conditions of producer cultivation, in particular on the availability of macro-, microelements or the presence of biosynthesis precursors, etc. [2].

In previous years the new Streptomyces netropsis IMV Ac-5025 strain was isolated by the researchers from D.K. Zabolotny Institute of Microbiology and Virology of the National Academy of Sciences of Ukraine. This strain biosynthesizes a polyene antibiotic complex with antagonistic properties against phytopathogenic micromycetes (representatives of Alternaria, 
Fusarium, Cladosporium genera). Other antibiotics, produced by the strain, inhibit phytopathogenic bacteria of Pseudomonas, Xanthomonas, Clavibacter genera. The strain also produces a wide range of other biologically active substances that have a growth-stimulating, adaptogenic effect on plants [4]. Among the polyene antibiotics, two fractions were identified: heptaene candidine and tetraene compound of unknown structure. There is no information about the last substance in Antibiotics database launched - NCBI $[5,6]$.

Polyene antibiotics are polyhydroxylated macrocyclic lactones and consist of 20-40 carbon atoms with from three to eight conjugated double bonds. The macrolactone usually contains a sixmembered hemiketal ring with a carboxyl group formed from the methyl branch by oxidation. Another structural feature of these substances is the presence of a deoxyamino sugar residue that is linked with the macrolactone nucleus by a glycosidic bond. After integration into the target cell, polyketide units disrupt its integrity, leading to metabolic leakage and death of the target cell [7].

Different classes of phytohormones are accumulated in the producer's biomass - physiologically active compounds that, as supposed, regulate the activity of streptomycetes and their interaction with plants $[8,9]$. Cytokinins play an important role in seed germination, stimulation of rhizogenesis and growth of the aerial part of plants. However, their participation in the metabolism of streptomycetes has not been studied. There are studies that have shown a positive effect of exogenous cytokinins on the development of bacteria of Streptomyces, Clostridium, Staphylococcus, Micromonospora, Bacillus, Rhizobium, Pseudomonas, Mycobacterium, and Ervinia genera. Phytohormones affect the production of antibiotics and the content of endogenous phytohormones, but for each producer and class of antibiotics, which differ in chemical structure, this relationship needs to be clarified. In addition, cytokinins have been shown to affect the growth and some physiological processes of cyanobacteria Anabaena doliolum, yeast Schizosaccharomyces acidodevoratus, and micromycetes of Verticillium and Fusarium genera, that indicating their possible role in S. netropsis IMV Ac-5025 metabolism [10].

Earlier we conducted a correlation analysis, which showed that among the whole spectrum of biologically active substances synthesized by the strain, the formation of antibiotics is most correlated with the cytokinins biosynthesis through isopentenyladenosine (iPA) [9]. To date, the effect of biologically active substances, formed by the producer, in particular phytohormones, on the biosynthesis of polyene antibiotics in soil streptomycetes has not been elucidated. Therefore, the aim of the research was to investigate the effect of exogenous iPA on the biosynthesis of polyene antibiotics and cytokinins by $S$. netropsis IMV Ac5025.

Materials and methods. $S$. netropsis IMV Ac5025 strain was gained from the collection of D.K. Zabolotny Institute of Microbiology and Virology of the National Academy of Sciences of Ukraine. The strain was cultured in submerged cultivation condition in synthetic (starch-ammonia) and organic (soy) nutrient media to obtain the biosynthesis of antibiotics and cytokinins under the action of exogenous iPA. The strain was stored in oaten (ISP-3) agar at $+4{ }^{\circ} \mathrm{C}[11,12]$.

S. netropsis IMV Ac-5025 was introduced into flasks with a nutrient medium, (containing soy broth $15 \mathrm{~g} / \mathrm{L}$, yeast extract $5 \mathrm{~g} / \mathrm{L}$, glucose $20 \mathrm{~g} / \mathrm{L}$ ) to receive the inoculum, and incubated on a rotary shaker at $+28 \pm 1{ }^{\circ} \mathrm{C}$ and $240 \mathrm{rpm}$ for 2 days. The inoculum was added in a quantity of $5 \%$ of the nutrient media volume and incubated under the same conditions for the next 7 days. Tne follow concentrations of exogenous iPA were used: $25 \mathrm{ng} /$ $\mathrm{mL}, 50 \mathrm{ng} / \mathrm{mL}, 100 \mathrm{ng} / \mathrm{mL}, 200 \mathrm{ng} / \mathrm{mL} 500 \mathrm{ng} / \mathrm{mL}$, and control variant without cytokinin addition. During the cultivation, we measured the glucose consumption by the glucose oxidase method using the Finetest Auto-cordingTM Premium test system ("Infopia 1td", South Korea), nutrient media $\mathrm{pH}$ changes by the ionometric method using the device (I-160 MI, UA). The producer biomass accumulation was analyzed by the gravimetric method wich was expressed in grams of absolutely dry biomass (ADB) per 1 liter of nutrient medium [4].

The polyene antibiotics were extracted from the producer's wet biomass by $96^{\circ}$ ethanol after 24 hours and then were recounted to $1 \mathrm{~g}$ of ADB. Ethanol extracts were applied on chromatographic plates TCL Silicagel $60 \mathrm{~F}_{254}$ ("Merck", Germany). Chromatography of the extracts was carried out in a solvent system - butanol: acetic acid: water (3:1:1). Pre-purified heptaene fraction (candidine) and tetraene compound synthesized by the strain were used as a control. Purification of these compounds was performed by chromatographic separation on chromatographic plates TCL Silicagel 60 F ${ }_{254}$ ("Merck", Germany) in a 
solution system for polyene antibiotics and then the extraction of antibiotics by $60^{\circ}$ ethanol was performed. Antibiotics were re-washed from the walls of the Eppendorf tubes, centrifuged and the obtained extracts were used as controls. The spots formed at the appropriate height of the plate were analyzed by the using of spectrodensitometer "Sorbfill" in the UV filter with a wavelength of $365 \mathrm{~nm}$ and identified as corresponding to each of the fractions. The device and software responded to the height of the peak, which corresponded to the fraction of candidine or tetraene compounds. The peak area indicated the amount of antibiotic and was supplemented with control. The total sum of polyene antibiotics was determined by summing the quantity of heptaene and tetraene fractions.

The content of cytokinins was determined in ethanolic extracts of wet producer's biomass and then was recounted to $1 \mathrm{~g}$ of ADB. Preliminary purification and concentration of them were performed on silica gel Silufol UV ${ }_{254}$ ("Chemapol", Czech Republic) plates in a mixture of solvents used sequentially: chloroform, $12.5 \%$ ammonia and ethyl acetate: acetic acid (20:1). Then we quantitatively applied samples and controls of cytokinins (zeatin was used) on chromatographic plates for the following separation of substances. Then, for the each sample, a silica gel layers corresponding to cytokinins were removed from the plate and transferred into Eppendorf tubes. Their extraction was carried out using $96^{\circ}$ ethanol. Samples were placed in a refrigerator for 1 day at $+4{ }^{\circ} \mathrm{C}$. On the next day, the samples were stirred and centrifuged. The obtained supernatant was transferred to Eppendorf tubes of smaller volume and left for 1 day in a thermostat at $+28{ }^{\circ} \mathrm{C}$ for the evaporating and concentrating. On the $3^{\text {rd }}$ day, the phytohormones were quantitatively washed from the walls of the Eppendorf tubes with appropriate solvents (as described above) and applied on the chromatographic alumina plates ("Merck", Germany) for quantitative analysis in chloroform: acetic acid (19:1) solvent mixture. Quantitative detection of cytokinins was performed by using a spectrodensitometer "Sorbfil". Chemically pure cytokinins: zeatin, zeatinribozid, isopentenyladenine, isopentenyladenosine ("Sigma-Aldrich", Germany) were used as standards [13, 14]. Calculations and statistical processing of obtained data were made by using computer programs Statistica 6.0 and Microsoft Excel 2010.
Results. It is known that the biosynthesis of antibiotics depends on the cultivation conditions, namely the composition of the nutrient medium, temperature, $\mathrm{pH}$, etc., and these conditions must be determined experimentally for each strain. The bacterial population during the growth passes through two phases: trophophase (phase of balanced growth, when the formation of primary metabolites is occur) and idiophase (phase of growth retardation and accumulation of secondary metabolites). We have shown that the growth curve of $S$. netropsis IMV Ac-5025 has a two-phase character. The first growth phase is trophophase that occurred from the $1^{\text {st }}$ to the $6^{\text {th }}$ day of cultivating and characterized by the rapid biomass accumulation, intensive consumption of basic nutrients (sources of Carbon, Nitrogen, Phosphorus, etc.). After the $6^{\text {th }}$ cultivating day we recorded the onset of idiophase, when the process of biomass accumulation was slowed down and the quantity of polyene antibiotics and other secondary metabolites began to grow. The nutrient media were enriched with the products of metabolism and cell autolysis and $\mathrm{pH}$ was shifted to the alkaline side (Fig. 1).

It is known that secondary metabolites, in particular antibiotics, begin to be intensively synthesized in the idiophase, while we have shown that polyene antibiotics in the producer biomass were formed on the first day of cultivation, that indicates their role in the streptomycetes metabolism [15].

In the synthetic medium the starch was the source of Carbon, which was enzymatically cleaved to glucose and used by the producer. The most intensively it was consumed during the trophophase during 1-3 days when its amount decreased up to $28 \%$ compared with the initial value. During this phase, the bacterial population intensively grew and biosynthesized primary metabolites. Starting from the $7^{\text {th }}$ day with the onset of the idiophase, glucose was completely utilized. In the organic nutrient medium glucose was added in the amount of $50 \mathrm{~g} / \mathrm{L}$ and on the $2^{\text {nd }}$ day it's amount decreased up to $40 \%$, and on the $5^{\text {th }}$ day - it was almost completely used, which is the characteristic of the trophophase. When its concentration was decreasing, the slowdown of biomass formation and antibiotic accumulation was observed. The $\mathrm{pH}$ value at the start point was 6.8 in the synthetic and 7.2 in the organic nutrient media. On the $3^{\text {rd }}$ day (trophophase period) it was 6.63 in the synthetic and 7.38 in the organic nutrient 
media. In the synthetic medium $\mathrm{pH}$ changed most significantly due to a precisely defined composition of the components of the synthetic nutrient medium.
Further we observed a tendency to shift the acidity level to the alkaline side and on the $10^{\text {th }}$ day $\mathrm{pH}$ has reached values 8 in both nutrient media.

A

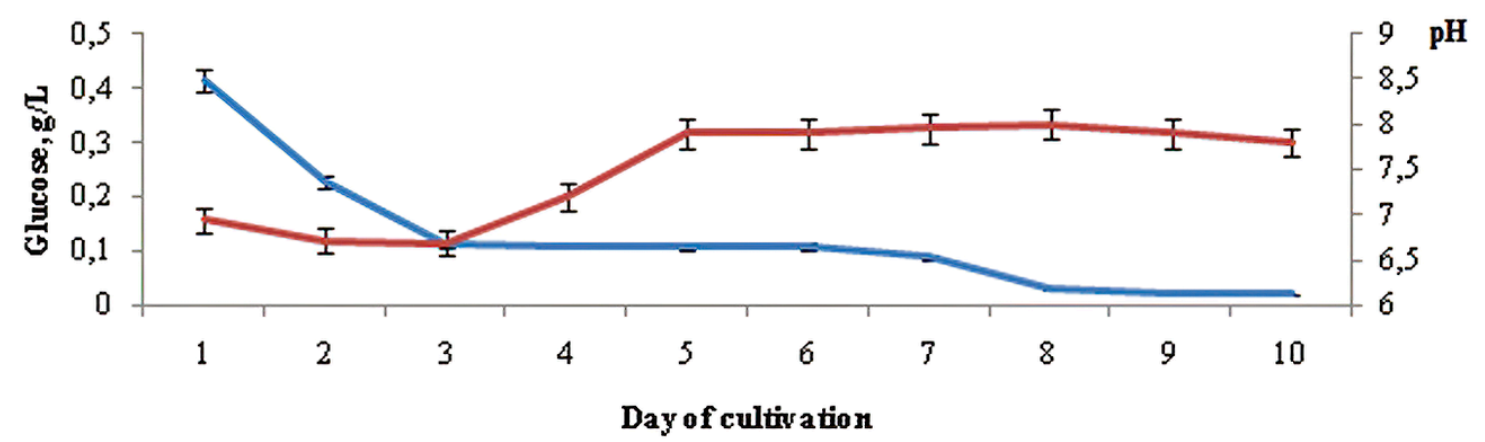

B

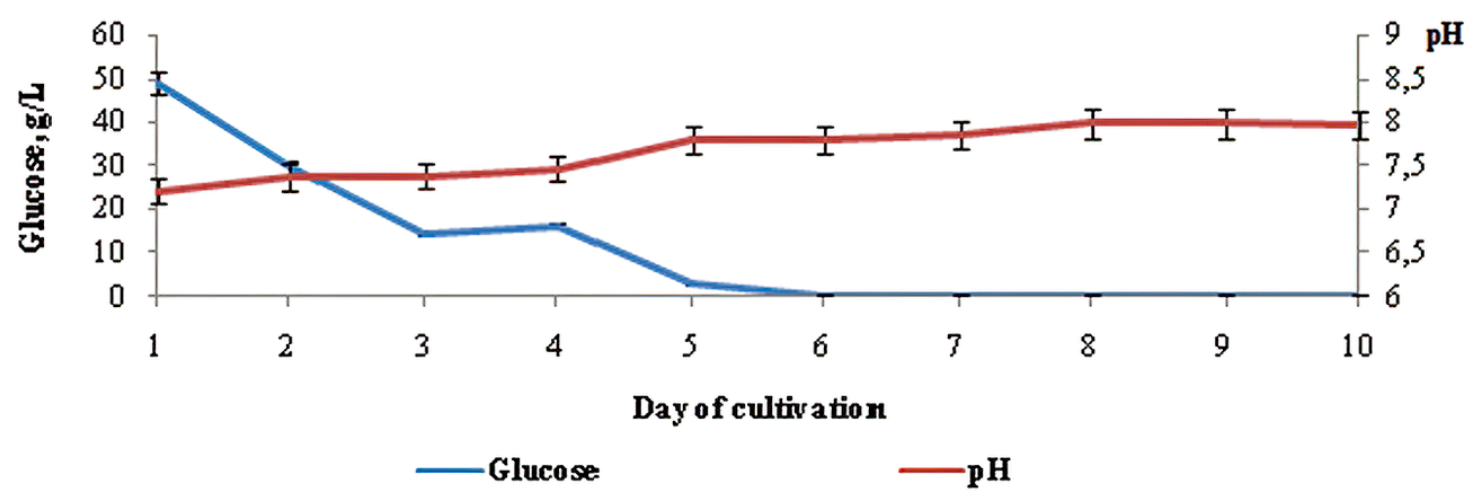

F i g. 1. Dynamics of glucose consumption and $\mathrm{pH}$ of nutrient media changes during the cultivation of $S$. netropsis IMVAc-5025 in synthetic (A) and organic (B) nutrient media

S. netropsis IMV Ac-5025 synthesized polyene antibiotic complex in which two fractions were identified: heptaene fraction (candidine) and tetraene fraction with unknown structure. In both nutrient media, the increase of biomass accumulation correlated with the increase of the polyene antibiotics amount, because they accumulate in the biomass. In the synthetic nutrient medium after the $7^{\text {th }}$ day, their quantity was by $74 \%$ higher than after the $1^{\text {st }}$ day, the amount of candidine increased 10-fold, and the tetraene fraction - 4-fold, the amount of biomass increased 2 -fold compared to the $1^{\text {st }}$ day. In the organic nutrient medium, the same trend was persisted. On the 7-8 ${ }^{\text {th }}$ days the amount of candidine increased 37 -fold, and the tetraene fraction -4 -fold, the total number of polyenes increased by $90 \%$, the biomass extent increased 4-fold. Thus, the largest amount of polyene antibiotics accumulated in streptomycetes cells on the $7^{\text {th }}$ day in the stationary growth phase (Fig. 2).
Due to the fact that both polyene antibiotics and cytokinins are intracellular metabolites, and given that exogenous cytokinins affect bacterial cell division, antibiotic accumulation, and the pool of endogenous cytokinins [10], it was appropriate to investigate the effect of exogenous iPA on the accumulation of antibiotics and cytokinins on the $7^{\text {th }}$ day of $S$. netropsis IMV Ac-5025 growth. We compared the biosynthetic capacity of the producer in different nutrient media. Synthetic nutrient medium is suitable to determine the quantity of metabolites synthesized de novo. However, the organic nutrient medium is richer of growth factors, precursors for metabolic biosynthesis, etc., as it contains organic components (corn extract, yeast extract, etc.). This allows to obtain more biomass and some compounds. Such media are used in biotechnological processes.

In the synthetic nutrient medium without the addition of cytokinin in the producer biomass the accumulation of candidine was $186.9 \mu \mathrm{g} / \mathrm{g}$ ADB. 
Under the action of different concentrations of iPA, this value decreased and ranged from 21.9 to 90.2 $\mu \mathrm{g} / \mathrm{g}$ ADB. The quantity of tetraene in the control variant was $712.6 \mu \mathrm{g} / \mathrm{g} \mathrm{ADB}$ and the addition of iPA caused the decrease of this value 12-fold which varied from $57.6 \mu \mathrm{g} / \mathrm{g}$ ADB to $497.3 \mu \mathrm{g} / \mathrm{g}$ ADB. The total amount of polyene antibiotics without the addition of iPA was $899.6 \mu \mathrm{g} / \mathrm{g}$ ADB and under the action of exogenous cytokinine it decreased and varied from 79.3 to $535.5 \mu \mathrm{g} / \mathrm{g}$ ADB. The lowest amount of polyene antibiotics was at 100 $\mathrm{ng} / \mathrm{mL}$ of iPA. Biomass accumulation at $500 \mathrm{ng} /$ $\mathrm{mL}$ of iPA increased by 1.4 times compared to the control. This suggested that exogenous cytokinins contributed to cell division and biomass increase, respectively, but the biosynthesis of polyene antibiotics was inhibited.

$687.9 \mu \mathrm{g} / \mathrm{g}$ ADB of candidine was detected in the biomass of $S$. netropsis IMV Ac-5025 in the organic nutrient medium without the addition of exogenous iPA. Under the action of $50 \mathrm{ng} / \mathrm{mL}$ of exogenous cytokinin, its amount decreased to the level of $18 \%$ of control. The amount of tetraene fraction in the control variant was $1747.0 \mu \mathrm{g} / \mathrm{g}$ ADB and under the action of $500 \mathrm{ng} / \mathrm{mL}$ of iPA it was $67 \%$ compared to the control. The sum of polyenes ranged from 1906.7 to $2752.7 \mu \mathrm{g} / \mathrm{g} \mathrm{ADB}$ and decreased with increasing of exogenous iPA concentration (Fig. 3).

A

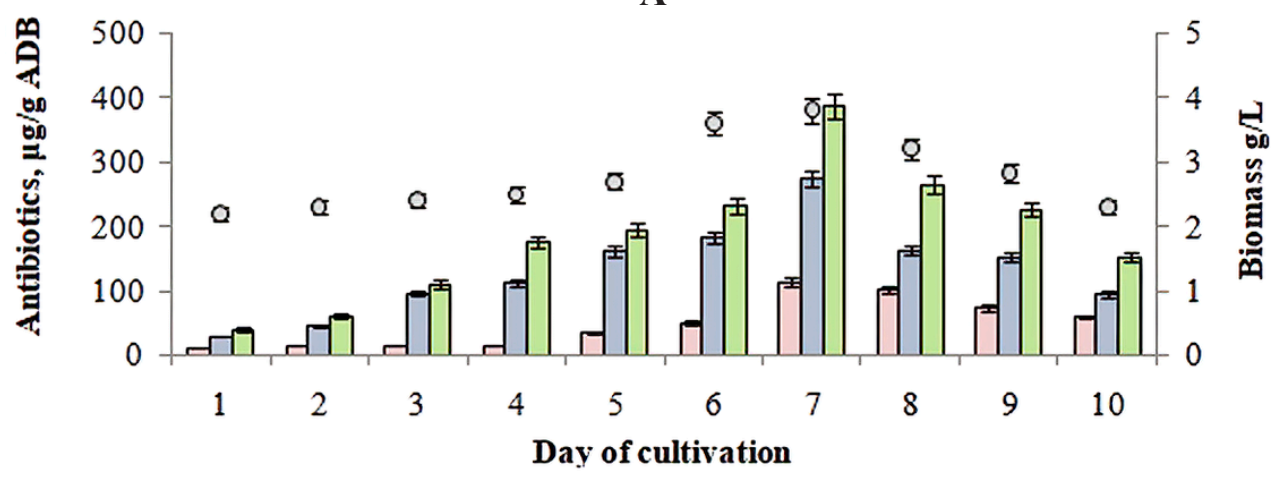

B

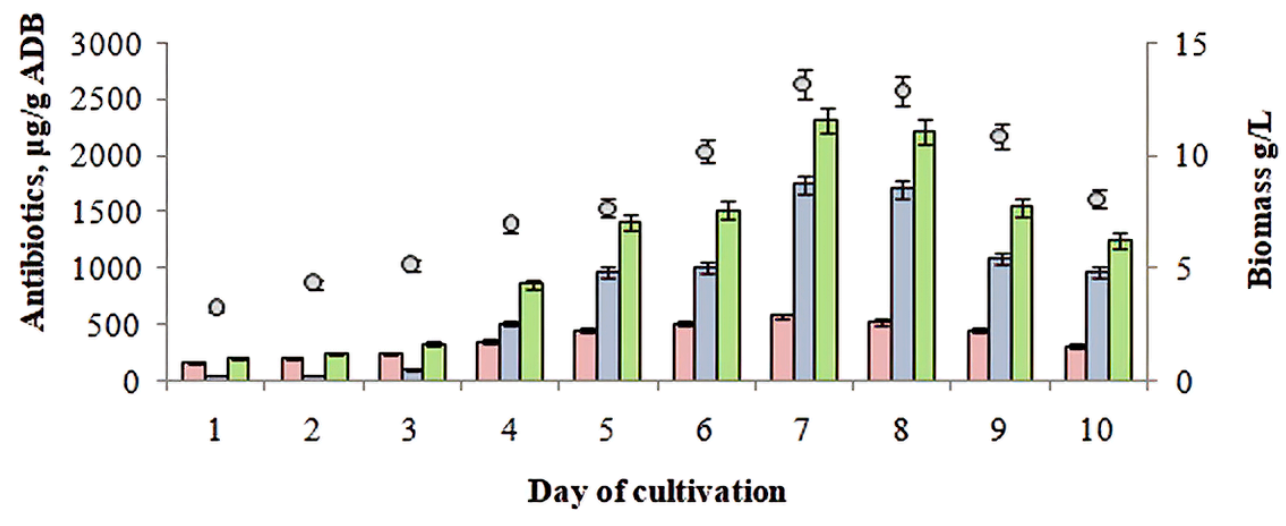

口Candidine $\quad$ Tetraene $\quad$ Sum of antibiotics oBiomass

F i g. 2. Dynamics of polyene antibiotics biosynthesis and biomass accumulation by S. netropsis IMVAc-5025 during submerged cultivation in synthetic (A) and organic (B) media

It was shown that exogenous iPA led to reduces of the accumulation of polyene antibiotics in S. netropsis IMV Ac-5025 biomass in both nutrient media, which is consistent with the results of a previous correlation analysis [9]. In general, in the organic nutrient medium in comparison with the synthetic, the amount of biomass was 4.5 -fold greater, and the accumulation of polyenes was 3 -fold higher, which indicated the advantages of its use in biotechnological processes.

Cytokinins, accumulated in S. netropsis IMV Ac5025 biomass, affect the growth and development of soil streptomycetes. These compounds are derived from adenine, similar in structure, but have different biological activity. According to the functional value, cytokinins can be divided into active free bases (zeatin and isopentenyladenine), which bind to the receptor and cause a physiological response 
A

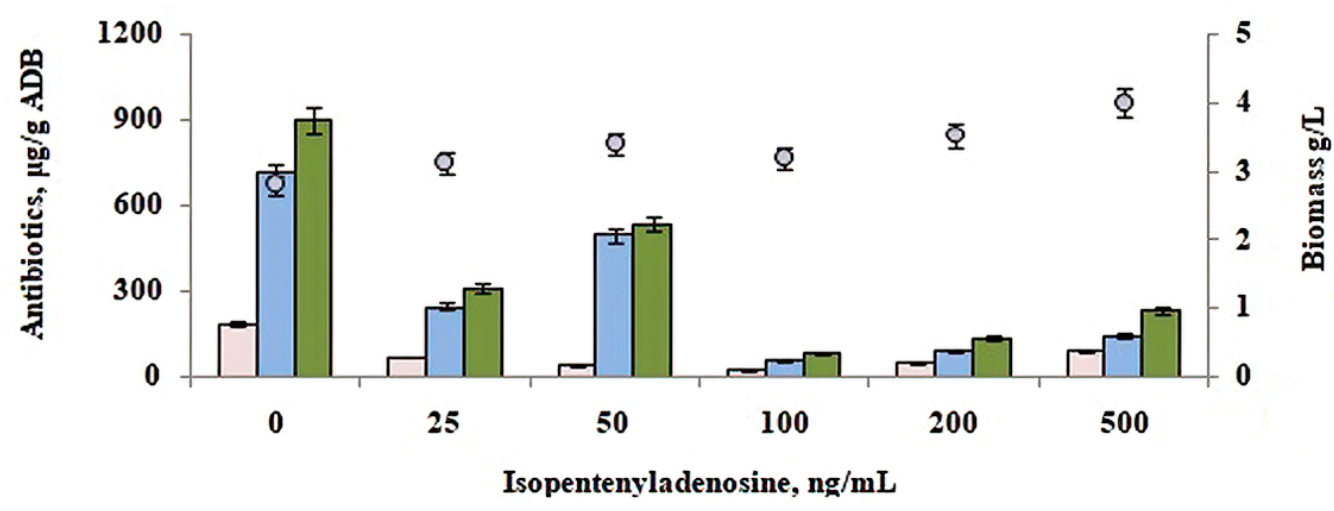

B

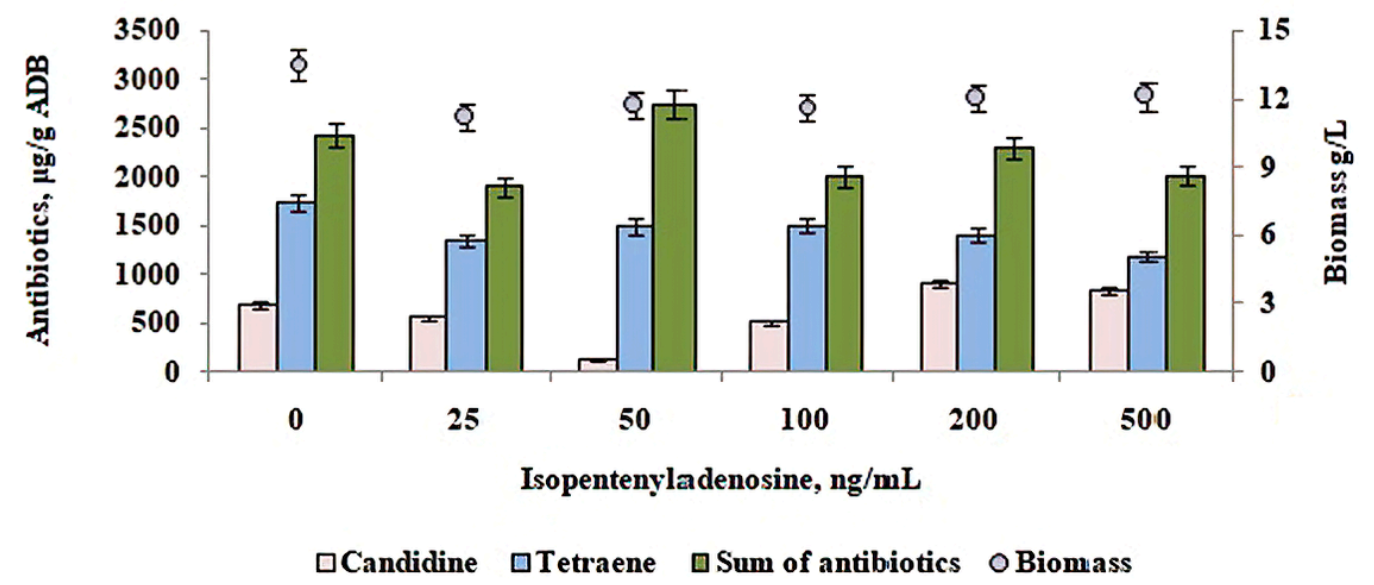

F i g. 3. Polyene antibiotics biosynthesis and biomass accumulation by $S$. netropsis IMV Ac-5025 under the action of exogenous isopentenyladenosine in synthetic (A) and organic (B) nutrient media

and conjugated forms with the minimal biological activity. They are converted to active forms as it needed. Cytokinin biosynthesis can be performed by mevalonate and non-mevalonate (also appearing as the mevalonate-independent pathway and the 2-C-methyl-D-erythritol 4-phosphate/1-deoxy-Dxylulose 5-phosphate (MEP/DOXP) pathway). It is known that in bacteria cytokinins can be formed due to tRNA degradation, but in most cases inactive cis-isomers of zeatin are formed, while active trans-isomers are formed by de novo biosynthesis $[10,16]$.

The reduction of polyene antibiotics and cytokinins accumulation under the action of exogenous iPA indicates the role of isopentinyladenosine in the metabolism of streptomycetes. IPA is formed from a key metabolite of the mevalonate pathway - DMAPP. Ways of cytokinin biosynthesis in bacteria that are not related to plants, and are not phytopathogens not studied completely $[17,18]$. There are data in the literature about the correlation of mevalonic acid levels and accumulation of polyene antifungal antibiotics, so there is a reason to believe that this metabolic pathway functions in the biosynthesis of cytokinins in soil streptomycetes, and mevalonic acid plays a role in the formation of polyenes [19]. Due to the fact that cytokinins are intracellular metabolites of the studied streptomycetes and are not detected in the culture fluid, it was important to test the effect of exogenous iPA on the pool of endogenous cytokinins of $S$. netropsis IMV Ac-5025. It was found that under the increasing of exogenous iPA concentration the biosynthesis of endogenous cytokinins by the producer was decreased (Fig. 4).

In the starch-ammonia nutrient medium the quantity of zeatin, zeatin-riboside, isopentyladenine and isopentenyladenosine varied under the action of exogenous substances, but there was a general tendency of the inhibition of endogenous cytokinins biosynthesis. At a concentration of $100 \mathrm{ng} / \mathrm{mL}$ of exogenous iPA, the amount of isopentenyladenosine and zeatin (formed from it) was the lowest: 0.282 and $0.319 \mu \mathrm{g} / \mathrm{g}$ ADB, which was $13 \%$ and $61.3 \%$ respectively of the control variant without the 
A

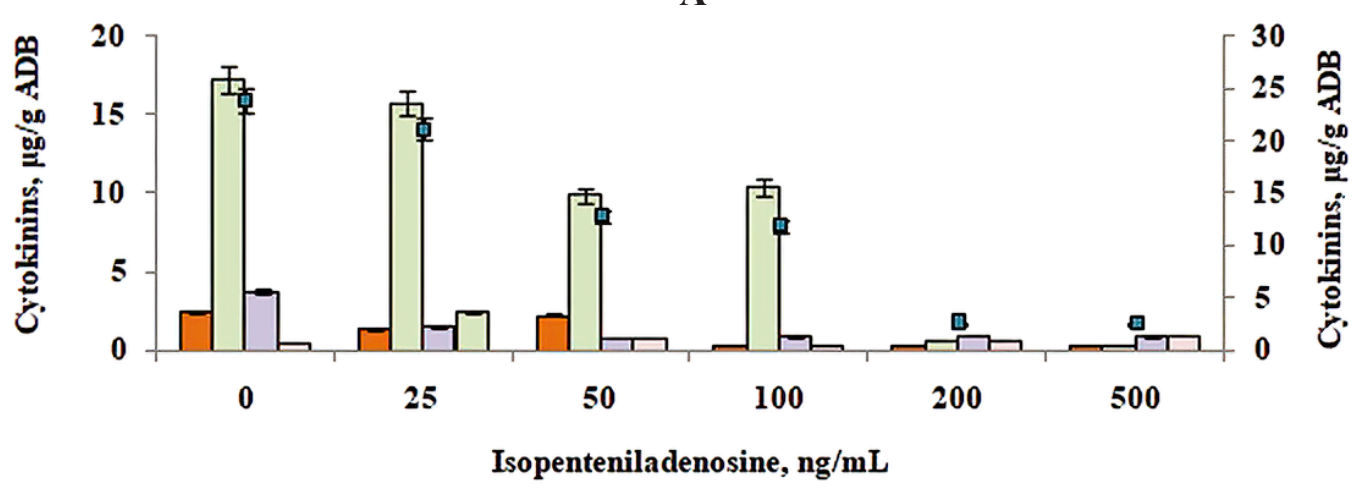

B

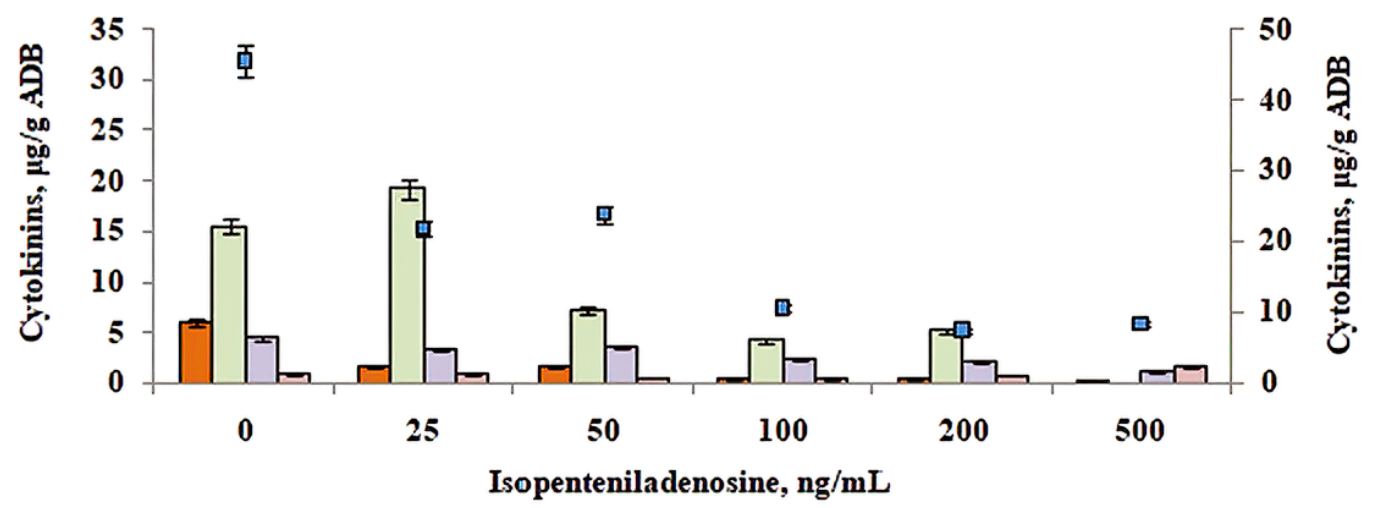

$\square$ Zeatin $\square$ Zeatin-riboside $\square$ Isopentyladenine $\square$ Isopentenyladenosine $\square$ Sum of cytokinins

\section{F i g. 4. Cytokinins biosynthesis by $S$. netropsis IMV Ac-5025 under the action of exogenous isopentenyladenosine in synthetic (A) and organic (B) nutrient media}

addition of iPA. Under the action of $500 \mathrm{ng} / \mathrm{L}$ of exogenous iPA, the biosynthesis of zeatin-riboside and isopentyladenine was the lowest. At the same concentration, the sum of cytokinins in the producer's biomass was the lowest $-10.7 \%$ of the control. The level of biosynthesis of endogenous cytokinins decreased under the action of exogenous iPA, because exogenous cytokinin was sufficient to perform its physiological functions.

In soy nutrient medium under the action of $200 \mathrm{ng} / \mathrm{mL}$ of exogenous iPA the lowest amount of zeatin and zeatin-riboside synthesized in the biomass of $S$. netropsis IMV-Ac 5025, which was $5.7 \%$ and $12.3 \%$, respectively, compared to the control. The lowest amount of isopentyladenine ( $25 \%$ of the amount in control) was found in the biomass under the action of $500 \mathrm{ng} / \mathrm{mL}$ of exogenous iPA. The smallest amount of endogenous isopentenyladenosine was accumulated at $100 \mathrm{ng} /$ $\mathrm{mL}$ of $\mathrm{PA}-42.1 \%$ compared to control. Taking into account that zeatin and zeatin-ribozide constitute a major part of cytokinins in streptomycetes biomass, the overall accumulation of synthesized cytokinins decreased under conditions of reduced biosynthesis of these compounds.

Discussion. After analyzing the literature data about the relationship between the streptomycetes biosynthesis of secondary metabolites, we suggested probable places where the biosynthetic pathways of polyene antibiotics and cytokinins intersect in soil streptomycetes. It is known that polyene antibiotics are formed due to the increase of the Carbon chain with the addition of polyketide sugars and due to the condensation of mevalonate and alkyl groups. The biosynthesis of type II polyketides usually begins with the addition of $\alpha$-carboxylated precursor, usually acetate to the acyl carrier protein, which is subsequently transferred to the active site of ketosyntase and then subjected to multiple elongation using malonyl-CoA as an element for forming a poly- $\beta$-keto chain. Next, ketoreductases and aromatases together with oxygenases and in some cases transferases convert the poly- $\beta$-keto chain into the aromatic nucleus of the polyketide. After that, polyene antibiotics are subjected to post- 
structural modifications (redox reactions, transfer of functional groups, hydrolysis, etc.), which gives the antibiotic functional properties [20].

Cytokinin biosynthesis in the mevalonate pathway involves two-step phosphorylation to form mevalonate-5-diphosphate, and other phosphorylation followed by decarboxylation results to the formation of isopentenyldiphosphate, which can be isomerized to dimethylallyl pyrophosphate (DMAPP). This substance is a precursor of cytokinins. DMAPP is an isomer of isopentenyl-pyrophosphate. The enzyme isopentenyl-pyrophosphate isomerase catalyzes the isomerization between DMAPP and iPA. Subsequent metabolic transformations of DMAPP lead to the formation of isopentinyladenosine isopentyladenine, zeatin and zeatin-riboside. Thus, the biosynthesis of polyene antibiotics and cytokinins can be linked through a common metabolite - mevalonic acid, which is used as an intermediate metabolite in the biosynthesis of cytokinins and to modify polyketide molecules to gain functional activity of polyene antibiotics [21]

In the biosynthesis of isoprenoids alkylating agents are used, such as $\alpha$-methyl, 2-ethyl-, 3-methoxy, 4-hydroxy-, amino groups, etc., which are also required for crosslinking $\alpha$-carbon chains of polyene antibiotics [22]. In the biosynthesis of cytokinins they are used for modifications of molecules, and in the biosynthesis of polyenes they are necessary for crosslinking of $\alpha$-carbon chains of polyketides, so in this place metabolic competition can also take place.

Thus, polyene antibiotics are biosynthesized by $S$. netropsis IMV Ac-5025 on the $1^{\text {st }}$ day of cultivation, which may indicate their role in the metabolism of soil streptomycetes. The advantages of using an organic nutrient medium in the biotechnological process for the accumulation of practically valuable metabolites in the required amount are shown. The largest amount of polyene antibiotics and producer biomass was accumulated in the stationary phase of growth (on the $7^{\text {th }}$ day), when the sum of polyene antibiotics increased by $90 \%$, biomass - 4-fold. We can suppose that the introduction of isopentenyladenosine into the culture medium indirectly reduces the accumulation of polyene antibiotics and cytokinins in the producer's biomass due to metabolic competition. On the other hand, the amount of biomass was increased, which indicate the role of iPA in the regulation of streptomycetes cell division.
Conclusions. The obtained results are important for understanding the relationship between the biosynthesis of polyene antibiotics and cytokinins in soil streptomycetes and provide an opportunity to explore potential regulators of the biosynthetic activity of the producer and use it biotechnological processes to obtain virtually valuable bioproducts with the required component composition.

Funding. The work was performed within the budget of the department.

\section{БІОСИНТЕЗ ПОЛІЕНОВИХ АНТИБІОТИКІВ I ФІТОГОРМОНІВ STREPTOMYCES NETROPSIS IMB АC-5025 ЗА ДІЇ ЕКЗОГЕННОГО ІЗОПЕНТЕНІЛАДЕНОЗИНУ}

\section{М.І. Лобода, Л.О. Білявська, Г.О. Іутинська}

\author{
Інститут мікробіології і вірусології \\ ім. Д.К. Заболотного НАН Украӥни, \\ вул. Академіка Заболотного, 154, \\ Київ, 03143, Україна

\section{Резюме}

Стрептоміцети $€$ активними продуцентами широкого спектру біологічно активних речовин 3 різнонаправленою біологічною активністю. Streptomyces netropsis IMB Ac-5025 продукує полієновий антибіотичний комплекс, у якому ідентифіковано дві фракції: гептаєновий кандидин та нова тетраєнова фракція невідомої структури, а також фітогормони. На сьогодні майже не вивчено вплив біологічно активних речовин, синтезованих грунтовими стрептоміцетами на біосинтез полієнових антибіотиків. Метою роботи було дослідити вплив екзогенного ізопентеніладенозину на біосинтез полієнових антибіотиків і цитокінінів S. netropsis IMV Аc-5025. Методи. Штам культивували глибинним способом в органічному (соєвому) і синтетичному (крохмало-аміачному) рідких поживних середовищах. Визначали накопичення біомаси (гравіметричний метод), споживання глюкози (глюкозо-оксидазний метод), зміну $\mathrm{pH}$ середовища культивування (іонометричний метод), біосинтез полієнових антибіотиків та фітогормонів (кількісна і якісна спектроденситометрична тонкошарова хроматографія). Результати проаналізовано в програмі Statistica v.10.0. Результати. Встановлено, що полієнові антибіотики накопичуються в біомасі продуцента вже на першу добу 
культивування, що свідчить про їх роль у метаболізмі стрептоміцетів. Найбільша кількість полієнових антибіотиків була накопичена продуцентом у стаціонарну фазу росту (7-ма доба культивування). Виявлено зниження накопичення полієнових антибіотиків і ендогенних цитокінінів в біомасі продуцента із зростанням концентрації екзогенного ізопентеніладенозину від 25 нг/мл до 500 нг/мл. Накопичення фракції тетраєну пригнічувалось більшою мірою у синтетичному - до 92\% і до $23 \%$ - в органічному поживних середовищах. Але кількість біомаси продуцента за дії екзогенної речовини зростала, що підтверджує позитивний

1. Franco-Correa M, Chavarro-Anzola V. Actinobacteria as plant growth-promoting rhizobacteria. Actinobacteria. Basics and Biotechnological Applications. 2016; 10:249-270.

2. Procopio RE, Silva IR, Martins MK, Azevedo JL, Araujo JM. Antibiotics produced by Streptomyces. Braz J Infect Dis. 2012; 16(5):466-471.

3. Biliavska LO, Pidlypska VA, Kozyrytska VY, Iutynska GO. Biosynthetical activity of soil streptomycetes - antagonists of plant-parasitic nematodes and phytopathogens. In: Proceedings of the 4th European Conf of Biology and Medical Sciences. 2015; Vienna, Austria. p. 10-17.

4. Biliavska LO, Efrenkova EV, Zenkova VA, Kozyrytska VE, Iutynska GO. [Soil streptomycete Streptomyces netropsis - producer of fungicidal substances]. In: Modern mycology in Russia: The 3rd International Mycological Forum; 2015; Moscow, Russia, p. 175-177. Russian.

5. Biliavska LO, Efymenko TO, Efremenkova OV, Iutynska GO. [Identification and antagonistic properties of the soil Streptomyces netropsis sp. 100]. Mikrobiol Z. 2016; 78(2):61-73. Russian.

6. Spurgeon D. Antibiotics database launched. The BMJ. 2001; 322(7291):881.

7. Hamilton-Miller JM. Chemistry and biology of the polyene macrolide antibiotics. Bacteriol Rev. 1973; 37(2):166-196.

8. Sousa JAJ, Olivares FL. Plant growth promotion by streptomycetes: ecophysiology, mechanisms and applications. Chem Biol Technol Agric. 2016; 3(24):1-12. вплив екзогенного цитокініну на поділ клітин S. netropsis IMV Аc-5025. Ізопентеніладенозин зменшував накопичення ендогенних цитокінінів в біомасі стрептоміцета. Висновки. Отримані результати свідчать про опосередкований метаболічний взаємозв' язок шляхів біосинтезу полієнових антибіотиків і цитокінінів у грунтових стрептоміцетів і дають основи для регулювання біотехнологічного процесу для утворення біопродукту з відповідним кількісним складом його компонентів.

Ключові слова: Streptomyces netropsis, полієнові антибіотики, кандидин, тетраєн, біосинтез метаболітів, цитокініни, ізопентеніладенозин.

9. Loboda MI, Voychuk SI, Biliavska LO. [Correlation dependence of the antibiotic compounds biosynthesis and other biologically active substances in soil streptomycetes]. Mikrobiol Z. 2019; 81(5):36-47. Ukrainian.

10. Tsavkelova EA, Klimova SY, Cherdyntseva TA, et al. Microbial producers of plant growth stimulators and their practical use: A review. Appl Biochem Microbiol. 2006; 42:117-126.

11. Semenow SM. [Laboratory media for actinomycetes and fungi]. Directory. M.: Agroprom publ.; 1990. Russian.

12. Iutynska GO, Biliavska LO, Kozyrytska VE. Zabolotny Institute of Microbiology and Virology, NASU. Strain S. marinolimosus - antagonist of phytopathogenic microorganisms. Patent of Ukraine 107122. 2014; Nov 25.

13. Sharshunova V, Schwartz V, Mikhalets N. [Thin layer chromatography in pharmacy and clinical biochemistry]. T1. M.: Mir ed.; 1980. Russian.

14. Savinsky SV, Dragovoz IV, Pedchenko VK. [Determination of zeatin, indolyl-3-acetic and abscisic acids from one plant sample using high-performance liquid chromatography]. Physiol and biochem cult plants. 1991; 23(6):606-614. Russian.

15. Harir M, Bendif H, Bellahcene M, Fortas Z, Pogni R. Streptomyces secondary metabolites. Basic Biology and Applications of Actinobacteria. Chapter 10. InTechPublishers; 2018. p. 99-122.

16. Hwang I, Sakakibara H. Cytokinin biosynthesis and perception. Physiol Plant. 2006;126(4):528538. 
17. Kakimoto T. Biosynthesis of cytokinins. J Plant Res. 2003;116(3):233-239.

18. Kanehisa M, Goto S. KEGG: Kyoto Encyclopedia of Genes and Genomes. Nucleic Acids Res. 2000; 28:27-30.

19. Steinman ID, Safferman RS, Lechevalier H. Role of inorganic salts and mevalonic acid in the production of a tetraenic antifungal antibiotic. Antibiotic Ann. 1958; 869-873.
20. Kong D, Lee MJ, Lin S, Kim ES. Biosynthesis and pathway engineering of antifungal polyene macrolides in actinomycetes. J Ind Microbiol Biotechnol. 2013; 40(6):529-543.

21. Frebort I, Kowalska M, Hluska T, Frebortova J, Galuszka P. Evolution of cytokinin biosynthesis and degradation. J Exp Bot. 2011; 62(8):24312452.

22. Calderone CT. Isoprenoid-like alkylations in polyketide biosynthesis. Nat Prod Rep. 2008; 25(5):845-853.

Received 12.03.2021 